\title{
THE RELATIONSHIP BETWEEN ORGANIZATIONAL CULTURE AND JOB SATISFACTION TOWARDS ORGANIZATIONAL COMMITMENT AND EMPLOYEE PERFORMANCE
}

\author{
Maswani, Syah Tantri Yanuar Rahmat, Anindita Rina \\ Faculty of Economics and Business, University of Esa Unggul, Indonesia \\ *E-mail: tantri.yanuar@esaunggul.ac.id
}

\begin{abstract}
The purpose of the study is to analyze the relationship between organizational culture, job satisfaction, organizational commitment and employee performance in the Government. In this study the population was 135 employees in the work unit of the Secretary General of the Ministry of Defense in 2018, and in this study, all of them acted as respondents. The data analysis technique uses the Structural Equation Modeling (SEM) analysis method. The results of the study show that organizational culture and job satisfaction have a positive effect on organizational commitment, so good organizational culture and job satisfaction can increase organizational commitment. Organizational commitment has a positive effect on employee performance, the higher organizational commitment can improve employee performance. organizational culture and job satisfaction have a negative influence on employee performance. This proves that organizational culture and decreased job satisfaction cannot affect employee performance in carrying out the main tasks and functions of the organization.
\end{abstract}

\section{KEY WORDS}

Organizational culture, job satisfaction, organizational commitment, employee performance.

Bureaucratic reform in Indonesia, the point is to make changes to the governance of development towards good governance. Good governance is characterized by, among others, high levels of performance, the existence of public accountability, transparency, efficiency, effectiveness, free from corruption, collusion and nepotism. Good governance is impossible to achieve its goals optimally without the contribution of all employees. Government work programs and budgets, both central and regional, which have been prepared in order to achieve certain targets, can be in vain if they are not supported by optimal employee performance. This shows that performance is a non-negotiable factor in organizational life, because performance is a prerequisite and at the same time the basic capital to build organizational performance. Organizational performance will not be optimal without the support of optimal employee performance.

Organizational culture is a fairly complex challenge in an organization. Organizational culture should be owned by companies including government agencies so that employees have values, norms, references, and guidelines that must be implemented. Organizational culture is also a unifying employee, reducing conflict, and motivating employees to carry out their duties well, so that it has a positive effect on behavior and performance. A company or organization that has a strong culture will produce good performance in the long run. Strong culture means that all employees have the same perception in achieving organizational goals. How to change the old organizational culture that is no longer in line with the new organizational cultural values of all employees for their voluntary desires and employee participation. People will not change by themselves just because they are governed and will only change if they want to be voluntary and conscious. People who are willing to leave the old ways are very few in number. The reality has been that many leaders and state apparatus are not only difficult to change but also often ignore the moral values and organizational culture of state apparatus, even though organizational culture is very important for improving employee performance. 
One of the main factors needed to build optimal performance is organizational commitment. This is necessary because high commitment will encourage individuals to strive and struggle as much as possible for the progress of the organization and itself. Moreover, high commitment will also encourage the growth of a loyal, dedicative, innovative, creative and anticipatory attitude that is needed by organizations in an effort to maintain and grow their existence. A person's performance is influenced by the level of job satisfaction that is owned. A person's job satisfaction is also influenced both from within and from outside. For the internal side, of course someone's job satisfaction will involve his commitment to work. Job satisfaction is also influenced by external factors, namely the organizational culture that has been applied in an agency.

(Negara, Makassar, Email, \& Basri, 2017) (variable organizational culture and organizational commitment) in the results of his research show that organizational culture will be positively related to employee commitment so that high communication, trust, and innovative culture are each positively related to organizational commitment. (Al-sada, 2017) (variable job satisfaction and organizational commitment) in the education sector shows that job satisfaction has a positive influence on organizational commitment. (Sawitri, Dyah, SE \&.et al, 2016) (variable organizational commitment and employee performance) in the results of research in the field of electricity shows organizational commitment has a significant positive influence on employee performance. (Barasa et al., 2018) (variable organizational culture and employee performance) the results of the study show there is a positive and significant influence of organizational culture on employee performance. (Ghufran \& Khan, 2016) (variable job satisfaction and employee performance) in the field of telecommunications results show that job satisfaction has a positive and significant impact on the perception of employee performance.

Previous research on organizational culture, job satisfaction, organizational commitment and employee performance has been done a lot; however, the research was not jointly examined in one study and research object. So the authors see that there is still a need to re-understand the organizational culture, job satisfaction, organizational commitment and employee performance Being a suggestion for research objects to conduct research on these variables. Based on the research gap above, the purpose of the research to be achieved is to provide an explanation of the influence of organizational culture, job satisfaction and organizational commitment mediated by the performance of employees in the work unit of the Secretariat General of the Ministry of Defense.

\section{LITERATURE REVIEW}

Culture is the attitude and behavior possessed by a group of people who live together (Belias \& Koustelios, 2014). The overall function of an organization or institution consists of many dimensions that influence the recruitment and management process, as well as relationships between employees and between employees and superiors. Therefore, certain internal cultures are usually formed in the organizational framework, which is a strategic and coherent approach to valuable assets, where people who work in it individually or together contribute to the achievement of their goals. The role of organizational culture in business organizations aims at the development and planning of human resource management, in recruitment and selection, learning and evolution, labor relations and work climate in business, health, safety, prosperity, compliance with regulatory requirements for employees, equal opportunities, and other matters relating to work relations. (Steven, 1996)

Job satisfaction is a positive and satisfied mood that results from assessing their experience and work (Saari \& Judge, 2004) Job satisfaction is the feeling of the employee towards work where the researcher sees it as the attitude of the employee (Davis, 2004). Job satisfaction is classified into three aspects, namely, on identifying the factors that influence job satisfaction such as the work environment, job characteristics and individual attributes. Conversely, retention and turnover are strongly influenced by job satisfaction (Al-sada, 2017) Factors such as supervision, promotion, and coworkers relationships are positively related to job satisfaction. In fact, personal factors such as goal orientation and contextual factors such 
as organizational culture and feedback channels lead to job satisfaction which ultimately affects the turnover rate in an organization (Joo \& Park, 2009).

According to (Hadian, 2017) said organizational commitment is an attitude that must be owned by every employee to show loyalty to the organization where they work, organizational commitment is closely related to the psychological aspects of acceptance and trust in the values and goals of the organization raised through the desire to maintain membership in organizational organizational commitment implies as something more than just passive loyalty to the organization, in other words implying an organizational commitment to employee relations with the company or organization actively.

Employee performance is the result of work that can be achieved by a person or group of people in an organization, in accordance with their respective authorities and responsibilities, in an effort to reach the relevant organization legally, morally and ethically (Barasa et al., 2018). Job requirements that are fulfilled optimally are indicative of achieving success in work. With this achievement work requirements are an important factor in the success of employee performance (Sutanto, 2016).

\section{VARIABLES RELATIONSHIP AND HYPOTHESES}

The relationship between organizational culture and organizational commitment is theoretically driven from popular writing. (Peters, T. J., \& Waterman, 1986) They suggest that organizational culture influences a variety of organizational and individual outcomes including productivity, performance, commitment, and self-confidence. This theoretical proposition has encouraged many subsequent empirical studies to investigate the relationship between organizational culture and organizational commitment. There are two main approaches adopted by researchers in investigating the relationship between organizational culture and organizational commitment. The first approach argues that there are several types of organizational culture, where people can compare which types of culture will have a positive effect on organizational commitment. The second approach connects the cultural dimension with organizational commitment to see which culture.

Dimensions have a significant relationship. There are a number of interesting empirical studies that use the first approach (Blair, Raymond, Eric, \& Karen, 2002) while only a few studies such as by (Jill, Graeme, \& Chee, 2003) using a second approach apart from different approaches, there is substantial evidence coming from both approaches related to positive relationships based on the fact that organizational commitment is a basic by-product of organizational culture. When organizational members internalize basic shared values and assumptions, and identify themselves with the organization, their organizational commitment is enhanced. Organizational culture that is characterized as collaborative, brotherhood, compactness; participatory, consensual, constructive, and supportive more likely to increase the level of organizational commitment. Thus, this study hypothesizes a positive relationship between organizational culture and organizational culture organizational commitment to organizational commitment. (Abdullah, Shamsuddin, \& Wahab, 2015).

$\mathrm{H} 1$. Organizational culture is positively related to organizational commitment.

Job satisfaction has a positive and significant influence on organizational commitment. The results of this study are supported by (Lambert, 1999), which states that job satisfaction has a positive correlation with organizational commitment and has the greatest correlation. (Ferdinand, 2006) explained that employees who are satisfied with their work are very committed to the organization, employees with job satisfaction generally see the organization as positive and respectful because they are optimistic about their work to meet their needs and desires. Job satisfaction refers to meeting the needs and values of individuals in the workplace assuming that individual needs and job characteristics are relatively stable.

$\mathrm{H} 2$. Job satisfaction is positively related to organizational commitment.

Organizational commitment is an attitude of loyalty that supports an organization, Organizational commitment means positive or negative attitudes of workers towards the entire organization and is not limited to tasks or work that must be done (Ghufran \& Khan, 2016). In organizational commitment a person has a strong sense of loyalty to the 
organization where the organization identifies itself (Correia \& York, 2012). To evaluate the relationship between organizational commitment and performance, (Riketta, M., \& Landerer, 2002) analyze and conclude a positive relationship between organizational commitment and employee performance. Job satisfaction and organizational commitment have a positive correlation with employee performance (Benkhoff, 1997).

H3. Organizational commitment is positively related to employee performance.

(Sinaga, Asmawi, Madhakomala, \& Suratman, 2018) explained that there is a direct positive effect of organizational culture on employee performance. The company's core values contain: Hard work, reliable, respectable, attentive and honest can improve employee performance; leaders and employees always maintain and comply with regulations and enforce a clear code of ethics to improve performance above the target; in general, employees have a work ethic and are diligent and continue to innovate by consistently developing and implementing more effective technologies to contribute to employee performance; Employees always give full dedication and integrity in carrying out their duties and responsibilities and can prioritize common interests and goals rather than personal and group interests in a culture that improves employee performance; leaders and employees always maintain and comply with regulations and enforce a clear code of ethics, creating trust that improves employee performance.

$\mathrm{H} 4$. Organizational culture is positively related to employee performance.

(Antoncic, 2011) explained that employee satisfaction has a positive effect on the four dimensions of work (general satisfaction with work; employee relations; remuneration, benefits and organizational culture; and employee loyalty). Therefore, this impact has a positive influence on the growth of the company.

H5. Job satisfaction is positively related to employee performance.

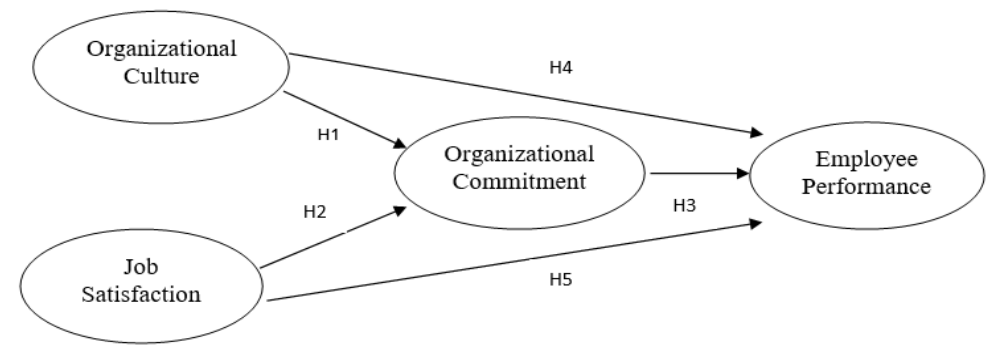

Figures 1 - Research Framework

\section{METHODS OF RESEARCH}

The study was conducted in December 2018 with the research method being descriptive analysis with a causality model to see the relationships between variables. The method of data analysis in this study uses Structural Equation Modeling (SEM) is an analytical technique used to test a series of complex relationships between simultaneous variables. This complex relationship consists of more than one dependent variable with many independent variables. Each construct is made by an indicator variable (Ferdinand, 2006). mentions that the number of representative samples to use SEM analysis techniques is 100200. The object of this research was carried out on public employees in the Ministry of Defense Secretariat General Administration Bureau with a total population of 135 respondents. The aspects studied were the influence of work culture variables, job satisfaction, organizational commitment and employee performance. This is an explanatory study that explains causal relationships and hypothesis testing. The data measurement method uses a Likert scale with one to five scale intervals.

In this study there are two exogenous variables namely organizational culture and job satisfaction and two endogenous variables namely organizational commitment and employee performance, but employee performance acts as a moderating variable that affects exogenous and endogenous variables. Measurement of organizational culture variables using dimensions (Smith, 2004), whose dimensions consist of physical, intellectual, 
emotional and spiritual dimensions; Job satisfaction variables use and adapt dimensions from (Fu, Deshpande, \& Zhao, 2011) which consists of salary, nature of work, supervision and work colleagues; organizational commitment variable using dimensions from (Herscovitch \& Meyer, 2002) propose and evaluate multidimensional conceptualizations of commitment to change and to examine the relationships between various forms of commitment and employee behavioral support; while employee performance variables use dimensions from (Mehrzi \& Singh, 2016) which revealed that performance appraisal included: (i) The number of jobs is the amount of work done in a predetermined period of time. (ii) Quality of work is the quality of work achieved based on requirements and readiness. (iii) Job knowledge is the breadth of knowledge about work and skills. (iv) Creativity is the authenticity of ideas raised and action skills. (v) Collaboration is the willingness to work with other people. (vi) Dependability is awareness and can be entrusted in terms of attendance and completion of work.(vii) Personal qualities related to personality, leadership, friendliness, and personal integrity.

Validity test is done with Confirmatory Factor Analysis that is by looking at the value Kaiser-Meyer-Olkin Measure of Sampling (KMO) and Measures of Sampling Adequacy (MSA). In this test the value obtained must be greater than 0.5 , which means that the analysis of factors is appropriate or suitable for use, and can be further processed (Malhotra, 2004). Validity test is done with Confirmatory Factor Analysis that is by looking at the value Kaiser-Meyer-Olkin Measure of Sampling (KMO) and Measures of Sampling Adequacy (MSA). In this test the value obtained must be greater than 0.5 , which means that the analysis of factors is appropriate or suitable for use, and can be further processed (Malhotra, 2004). The organizational culture scale consists of 7 questions and 1 of them is invalid so there are 6 questions left, Job satisfaction scale consists of 6 questions and 2 of them are invalid so there are 4 questions left, the scale of organizational commitment consists of 6 questions and 2 of them are invalid so there are 4 questions left, Employee performance scale consists of 6 questions and 1 of them is invalid so there are 5 questions left. Value reliability test Alpha Cronbach greater than or equal to 0.7 which means reliable that can be said to be operational-operational organizational culture, job satisfaction, organizational commitment and employee performance can be said to be trusted as a tool for collecting data in research. The next stage, the data is processed using the SEM analysis method.

\section{RESULTS AND DISCUSSION}

Our research focuses on organizational commitment and employee performance as a consequence of organizational culture and job satisfaction where the results show that from the four hypotheses proposed data obtained supports the hypothesis and data does not support the hypothesis, as we have done SEM testing, can be seen in Figure 2.

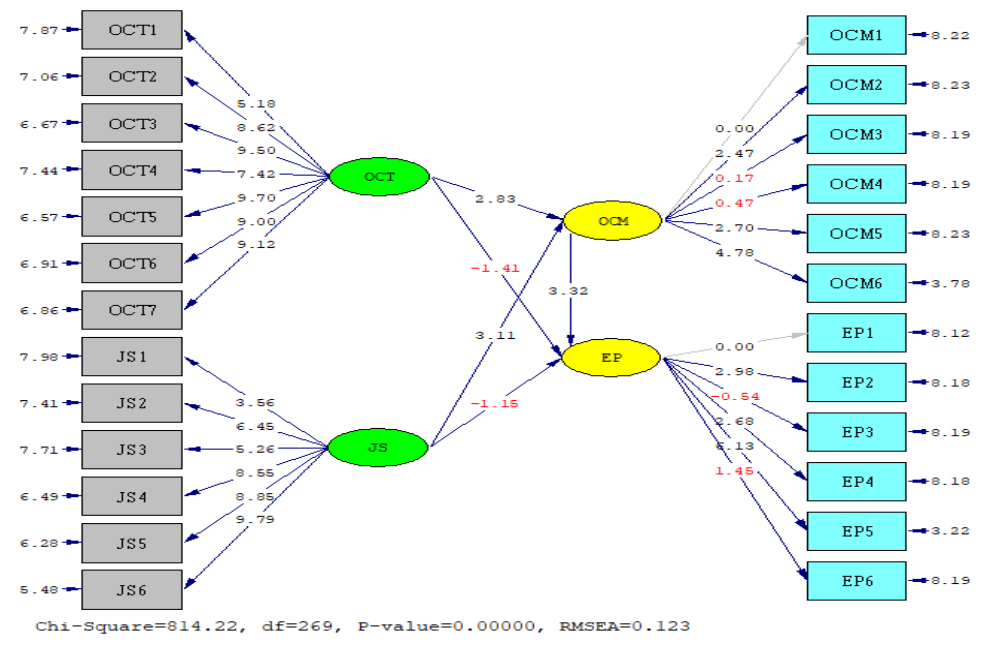

Figure 2 - Path Diagram of T-Value 
Based on Figure 2 above which is the hypothesis in this study, presented in the following structural equation:

Table 1 - Hypothesis Testing Research Model

\begin{tabular}{|c|l|c|c|}
\hline Hypothesis & \multicolumn{1}{|c|}{ Hypothesis Statement } & Value T-Value & Information \\
\hline $\mathrm{H}_{1}$ & $\begin{array}{l}\text { A good organizational culture will increase organizational } \\
\text { commitment }\end{array}$ & 2,83 & Data supports the hypothesis \\
\hline $\mathrm{H}_{2}$ & $\begin{array}{l}\text { High Job Satisfaction can increase Organizational } \\
\text { Commitment }\end{array}$ & 3,32 & Data supports the hypothesis \\
\hline $\mathrm{H} 3$ & $\begin{array}{l}\text { High organizational commitment can improve employee } \\
\text { performance }\end{array}$ & $-1,41$ & $\begin{array}{c}\text { Data does not support the } \\
\text { hypothesis }\end{array}$ \\
\hline $\mathrm{H}_{4}$ & $\begin{array}{l}\text { Good organizational culture can improve employee } \\
\text { performance }\end{array}$ & $-1,15$ & $\begin{array}{c}\text { Data does not support the } \\
\text { hypothesis }\end{array}$ \\
\hline $\mathrm{H}_{5}$ & High Job Satisfaction can improve Employee Performance \\
\hline
\end{tabular}

\section{DISCUSSION OF RESULTS}

On the results of testing the first hypothesis $(\mathrm{H} 1)$, it was found that the results of the analysis supported the $\mathrm{H} 1$ hypothesis, that good organizational culture would increase organizational commitment by 2.83. This shows that with the condition of a good organizational culture, the level of organizational commitment of its employees will also be higher. These results further reinforce the research that was previously carried out by (Abdullah et al., 2015) where the results of this study hypothesize a positive relationship between organizational culture and organizational culture organizational commitment to organizational commitment. Thus organizational culture becomes an important part in increasing organizational commitment within the organization.

The results of testing the second hypothesis $(\mathrm{H} 2)$, it was found that the results of the analysis supported the $\mathrm{H} 2$ hypothesis, namely high job satisfaction can increase organizational commitment by 3.11. This shows that the higher the job satisfaction of the employees, the more satisfied their employees will be in carrying out their work. These results further reinforce the research that was previously carried out by (Ferdinand, 2006) explained that employees who are satisfied with their work are very committed to the organization, employees with job satisfaction generally see the organization as positive and respectful because they are optimistic about their work to meet their needs and desires.

The results of testing the third hypothesis $(\mathrm{H} 3)$, it was found that the results of the analysis supported the $\mathrm{H} 3$ hypothesis, namely high organizational commitment can improve employee performance by 3.32. This shows that the higher a person's organizational commitment, the higher the employee's performance towards the organization. This result is also supported by research conducted (Ghufran \& Khan, 2016) Organizational commitment is an attitude of ongoing loyalty to an organization, organizational commitment means positive or negative attitudes of workers towards the entire organization and not limited to tasks or work.

The results of testing the fourth hypothesis $(\mathrm{H} 4)$, It was found that the results of the analysis did not support the $\mathrm{H} 4$ hypothesis, namely that organizational culture did not have a significant and positive influence on employee performance, this result further reinforced the research that had previously been done by (Pawirosumarto \& Sarjana, 2017). The results of the study explain that organizational culture does not have a significant and positive influence on employee performance. So that the presence of an organizational culture that is not good then the performance of its employees will also be low. Research in the Administrative Bureau of the Secretary General of the Ministry of Defense shows that organizational culture has no significant effect on employee performance, so that the organizational culture in the administration bureau of the Secretary General of the Ministry of Defense does not have a big influence towards improving employee performance, Based on empirical observations in the field, organizational culture in the Secretariat General of the Ministry of Defense functions as social knowledge, identity and behavior of employees. The organizational culture currently in the Ministry of Defense General Secretariat is considered 
to be less than optimal for employees, so it is not used as a reference for their behavior and activities in completing work.

The results of testing the fifth hypothesis $(\mathrm{H} 5)$, It was found that the results of the analysis did not support the hypothesis $\mathrm{H} 5$, namely job satisfaction did not have a significant and positive effect on employee performance. This shows that employee performance as perceived by employees at the General Secretariat of the Ministry of Defense is not significantly affected by job satisfaction. The results of this study are supported by (Paais, Kristen, \& Maluku, 2018) states that the insignificant influence between the variable job satisfaction on employee performance is characterized by the value of loading a low factor between job satisfaction and employees with a high probability value.

Based on empirical observations in the field, Job satisfaction felt by employees of the TU Secretariat General of the Ministry of Defense does not affect the performance of employees in carrying out the duties and functions of the organization. This means that if employee job satisfaction decreases, then employee performance has no effect. Conversely, improving employee performance is not always caused by higher job satisfaction felt by employees. Empirically, this fact can be proven that even though employees are dissatisfied, performance continues to run well. The indicator for variable employee performance associated is based on work quality, which is based on position, rank and class of each employee.

\section{MANAGERIAL IMPLICATIONS}

In organizational governance organizational culture is the implementation of the noble values of the Pancasila. In government organizations must be realized in all indicators both organizational culture, job satisfaction, organizational commitment and employee performance within the organization. Organizational cultural values that are influenced by elements of the country's philosophy can form a work system and work environment that are disciplined, effective, efficient. Planting a work culture on government organizations is important as the government's efforts to carry out the people's mandate in providing protection and services.

In this study, the organization is expected to make changes to organizational culture, job satisfaction by referring to organizational commitment and employee performance. To improve organizational culture, job satisfaction towards organizational commitment and employee performance can be proposed by looking at the dimensions used in this study. The first dimension is the physical, intellectual dimension, emotional and spiritual, which describes employees in the work unit of the Secretariat General of the TU Bureau of TU showing an attitude that obeys the applicable rules, a culture of mutual respect and respect for fellow employees based on class and rank levels so that employees who have a higher rank and class will be respected. The cultural values that apply in the work environment of the Secretariat General of the Ministry of Defense have a good impact on the organization.

Furthermore, the second dimension, namely the salary, the nature of work, supervision and coworkers from employee job satisfaction has decreased due to the increase in government salaries that have not increased in several years, this is of particular concern to the central government. The nature of the work felt by employees is increasingly greater due to the large number of newly built application systems and limited human resources (HR) thus increasing the workload for employees, it is hoped that the government will recruit new employees to assist the organization's duties and functions.

Organizational commitment is seen from the implications of the third dimension, namely proposing and evaluating the multidimensional conceptualization of commitment to change and for testing the relationship between various forms of commitment and support for employee behavior. This approach reflects that an employee's commitment will be stronger if his experience in an organization is consistent with his expectations, and satisfies his basic needs and vice versa. Goal Congruence Orientation of an apparatus within the organization emphasizes the extent to which his personal goals are in line with organizational goals.z 
Implications of employee performance as the fourth dimension, namely performance appraisal, among others: Number of jobs, quality, knowledge of work, creativity, collaboration, dependability, personal qualities such as leadership and friendliness. To support the realization of a good government, of course a good performance measurement system is needed. This performance measurement system will integrate the process of improving performance through the stages from planning to evaluating its performance. A good performance measurement system will be useful for a variety of things including being able to be used to implement a system of reward and punishment, evaluating the efficiency, effectiveness, and economics of programs and activities, improving performance, and others.

\section{CONCLUSION}

The results can be concluded from this study: (1) there is an influence of organizational culture on organizational commitment to the work unit of the administration bureau secretary general of the ministry of defense, Central Jakarta, it can be said that a good organizational culture will increase organizational commitment; (2) there is the influence of job satisfaction on organizational commitment in the work unit of the administration bureau secretary general of the ministry of defense, Central Jakarta, it can be said that high job satisfaction can increase organizational commitment; (3) there is an influence of organizational commitment on the performance of employees in the working unit of the administration bureau secretary general of the ministry of defense, Central Jakarta, it can be said that high organizational commitment can improve employee performance; (4) there is no influence between organizational culture on employee performance in the environment of the administration bureau secretary general of the ministry of defense, Central Jakarta; (5) there is no influence between job satisfaction on employee performance in the administration bureau secretary general of the ministry of defense Central Jakarta environment.

The limitations of the study refer to several weaknesses in this study. Some limitations contained in this study are: (i) This research was only carried out in the work unit of the administration bureau Secretariat General of the Ministry of Defense. (ii) This study only discusses the influence of organizational culture, job satisfaction on organizational commitment and employee performance. (iii) The inconsistency of respondents' answers in answering the questionnaire (questionnaire) and working conditions that made respondents not comfortable enough when answering the questionnaire (questionnaire) submitted to them. (iv) The form of a digital questionnaire made some respondents over 35 years old quite difficult in the filling process.

Future research development is expected to be able to add other variables that affect work commitment and employee performance. Further research is expected to be carried out by expanding the scope of research, for example by using samples not only from one work unit but more than one work unit and increasing the number of samples studied.

\section{REFERENCES}

1. Abdullah, N. H. (2015). Does organizational culture mediate the relationship between transformational leadership and organizational commitment ? 4, 18-32.

2. Al-sada, M. (2017). Influence of organizational culture and leadership style on employee satisfaction, commitment and motivation in the educational sector in Qatar, 12(2), 163188. https://doi.org/10.1108/EMJB-02-2016-0003

3. Antoncic, J. A. (2011). Employee satisfaction, entrepreneurship and firm growth: a model, 111(4), 589-607. https://doi.org/10.1108/02635571111133560

4. Barasa, L. (2018). International Review of Management and Marketing Determinants of Job Satisfaction and it's Implication on Employee Performance of Port Enterprises in DKI Jakarta. International Review of Management and Marketing, 8(5), 43-49.

5. Belias, D., \& Koustelios, A. (2014). Organizational Culture and Job Satisfaction: A Review, 4(2), 132-149.

6. Benkhoff, B. (1997). Disentangling organizational commitment the dangers of the OCQ 
for research and policy, 26, 1-16.

7. Blair, D., Raymond, F., Eric, A., \& Karen, S. (2002). The relationship between hospital unit culture and nurses' quality of...

8. Correia, S. (2012). Satisfaction with job aspects : Do patterns change over time? 65, 5-6.

9. Davis, G. (2004). Job satisfaction survey among employees in small businessesJournal of Small Business and Enterprise Development; 2004; 11, 4;, pp.495-345.

10. Ferdinand, A. (2006). Management Research Methods: Guidance for Writing Minithesis, Thesis, and Dissertation of Management Science. Economic Faculty. Semarang: Diponegoro University.

11. Fu, W., Deshpande, S. P., \& Zhao, X. (2011). The Impact of Ethical Behavior and Facets of Job Satisfaction on Organizational Commitment of Chinese Employees, 537-543. https://doi.org/10.1007/s10551-011-0928-4

12. Ghufran, H. (2016). The Effect of Reward Systems, Organizational Commitment and Experience on Job Satisfaction, 11(2015), 35-50.

13. Hadian, D. (2017). The Relationship Organizational Culture and Organizational Commitment on Public Service Quality; Perspective Local Government in Bandung, Indonesia. International Review of Management and Marketing, 7(1), 230-237.

14. Herscovitch, L. (2002). Commitment to Organizational Change: Extension of a ThreeComponent Model, 87(3), 474-487. https://doi.org/10.1037//0021-9010.87.3.474

15. Jill, L. (2003). Organization Culture: Association With Commitment, Job Satisfaction, Propensity to Remain, and Information Sharing in Taiwan, 11, 1; ABI/INFORM Collection.

16. Joo, B. B., \& Park, S. (2009). Career satisfaction, organizational commitment, and turnover intention the effects of goal orientation, organizational learning culture and developmental feedback. https://doi.org/10.1108/01437731011069999

17. Lambert, E. G. (1999). A path analysis of the antecedents and consequences of job...

18. Mehrzi, N. (2016). Competing through employee engagement, 65(6), 831-843.

19. Negara, L.A. (2017). Effects of Organizational Transformation and Culture on Employees Performance Muliaty Jasruddin, 11(3), 1287-1292.

20. Paais, M., Kristen, U., \& Maluku, I. (2018). Effect of work stress, organization culture and job satisfaction toward employee performance in bank Maluku, 17(5), 1-13.

21. Pawirosumarto, S., \& Sarjana, P. K. (2017). The e ff ect of work environment, leadership style, and organizational culture towards job satisfaction and its implication towards employee performance in Parador Hotels and Resorts, Indonesia, 59(6), 1337-1358. https://doi.org/10.1108/IJLMA-10-2016-0085

22. Peters, T. J., \& Waterman, R. H. (1986). In search of excellence: Lessons from America's best-run companies. New York: Harper Collins Publishers.

23. Riketta, M., \& Landerer, A. (2002). Organizational commitment, accountability, and work behavior: A correlational study, 653.

24. Saari, L. M., \& Judge, T. A. (2004). Employee attitudes and job satisfaction, 43(4), 395407. https://doi.org/10.1002/hrm.20032

25. Sawitri (2016). The Impact of Job Satisfaction, Organization Commitment, Organization Citizenship Behavior (Ocb) On Employees' Performance, 9(October 2016), 1-23.

26. Sinaga, H. G., Asmawi, M., Madhakomala, R., \& Suratman, A. (2018). Effect of Change in Management, Organizational Culture and Transformational Leadership on Employee Performance PT. Adhya Tirta Batam, 8(6), 15-23.

27. Smith, J. A. M. (2004). The relationship between critical dimensions of organizational culture and employee commitment.

28. Steven, M. (1996). Organizational commitment across cultures: The impact of antecedents of Korean Employees Reproduced with permission of the copyright owner. Further reproduction prohibited without permission.

29. Sutanto, E. M. (2016). The impact of recruitment, employee retention and labor relations to employee performance on batik industry in Solo City, Indonesia, 17(2).

30. Hadian, D. (2017). The Relationship Organizational Culture and Organizational Commitment on Public Service Quality; Perspective Local Government in Bandung, Indonesia. International Review of Management and Marketing, 7(1), 230-237. 